\title{
LAOS: SEARCH FOR PEACE IN THE MIDST OF WAR
}

\author{
Paul F. Langer
}

December 1967 


\section{LAOS: SEARCH FOR PEACE IN THE MIDST OF WAR}

Paul F. Langer*

The RAND Corporation, Santa Monica, California

As Laos entered 1967 , the picture looked very bleak. In theory, the strategically important country had been neutralized and sealed against foreign intervention by the Geneva Accords of 1962. The three feuding political factions -- "rightists," "neutralists," and Communist-led Neo Laos Hak Sat (commonly called the Pathet Lao) -- had agreed to make peace with each other and to rule jointly the country through a government of national union. Unfortunately for the Laotian people, the practice was another matter.

In Vientiane, the administrative capital on the Mekong, neutralist Prince Souvanna Phouma remained at the helm, but

* Any views expressed in this paper are those of the author. They should not be interpreted as reflecting the views of The RAND Corporation or the official opinion or policy of any of its governmental or private research sponsors. Papers are reproduced by The RAND Corporation as a courtesy to members of its staff.

This paper was prepared for publication in the Asian Survey. 
at cabinet meetings the chairs reserved for the Pathet Lao representatives stood empty. The Prime Minister was presiding over a rump government and his authority extended only to a part of the country. In 1963, Souvanna's halfbrother, Prince Souphanouvong, the nominal leader of the NLHS, had withdrawn with his friends into the western regions of the country. From there, with their back against North Vietnam, the Pathet Lao were carrying on a guerrilla-style "war of national liberation" against the Vientiane government. In this they had the full backing of the North Vietnamese who provided generous support to their Lao allies including a sizable number of armed forces.

To make matters worse, the previous year had been one of disasters and crises: a catastrophic flood had ruined much of the rice crop; the Prime Minister and the Nationa1 Assembly had clashed head-on so that the parliament had to be dissolved and new elections called to break the deadlock; finally, ex-strongman General Phoumi Nosavan was plotting a comeback from his exile in Thailand while General Kong Le was engaged in a losing struggle to retain control over his neutralist forces and air force General Thao Ma was dropping bombs on his enemies in Vientiane's 
military headquarters. There was also fear that the escalating conflict in neighboring Vietnam might eventually engulf all of Laos. To the north, Communist China in the throes of its Cultural Revolution posed another question mark.

But Laos came through 1967 remarkably well. As Prince Souvanna Phouma returned from a tour of Western capitals toward the end of the year, he could be reasonably satisfied. His political position had been consolidated. Not a single attempt had been made during the year to overthrow his government through military force. The threat of famine had been averted. And, the military balance of power in the country was if anything favoring the non-Communist side.

- In January 1967 , some 600,000 voters (out of a total estimated population of 2.3 million under government contro1) went to the polls. As anticipated, the new National Assembly reflected more faithfully than its predecessor the real power and influence of the coalition made up of the Prime Minister, most of the country's leading families, and the major military leaders in Vientiane and the four other regions. 
But in 1967, Souvanna -- very much the French-educated aristocrat -- continued to lack, unlike other Lao politicians, a solid regional power base or genuine mass support. His position of leadership was owed essentially to the fact that he had long been known as the leading proponent of a neutralist policy for his country. This policy was accorded international blessing by the Geneva agreements, the general lines of which both the United States and the Soviet Union wish to preserve in Laos.

Another source of strength for Souvanna is his capacity for accommodating himself to the realities of Lao politics, above all the continued existence of a pronounced regional power pattern and the important role a few prominent families play in it. Their interests must be considered and implicitly acknowledged in the selection of National Assemblymen, in the make-up of the cabinet, and in dividing the spoils of civilian and military office.

Having consolidated his political position and forged an alliance with certain influential families (especially the Sananikones of Vientiane), Souvanna, in 1967 set about the task of giving his country a more efficient government and greater national cohesion. He opened up access to the levers of command to a few able men in their forties who 
had been restless for some time and tended, barred from positions of responsibility, to become nuclei of antigovernment agitation. Without touching the tripartite arrangements regarding the distribution of ministerial portfolios among the three factions, the Prime Minister injected new blood into those positions immediately below those of ministerial rank. These new appointees were finding a kindred spirit in a hold-over from Souvanna's previous cabinet, Sisouk n Champassak, a young, we11trained and most able cabinet minister concerned with economic and financial policies.

A member of the prestigious and most powerful southern family which is headed by Prince Boun Oum, leader of the "rightist faction," Sisouk is by definition classified in the tripartite nomenclature of Laos as a "rightist." But in the past few years, these political labels have begun to lose significance as the dividing line between the two non-Communist factions has become increasingly blurred with acceptance by both parties of the implications of Laos' international position. This process made rapid progress in 1967 as important figures with strong personalities disappeared from the political scene or lost influence. General Kong Le, once the charismatic young 
leader of the neutralist forces, was compelled by his own men to resign and went to Paris to lead the life of an exile. The rightwing contender for power General Phoumi Nosavan was forced to remain in exile in Thailand and saw his hopes for a successful political comeback fade away as time went by.

Not altogether without justification has Laos been called "a state by diplomatic courtesy." Certainly it is premature to speak of effective Lao nationalism or Lao national consciousness. Divisive forces and conditions continue to prevail in Laos: traditional regionalism and vested local interests; the mountainous topography of the country and the undeveloped, largely autarkic state of its village economy; the near total absence of means of transportation and communications in most rural areas of Laos; the presence of a variety of mutually antagonistic (or at best indifferent) ethnic minorities united only in their suspicion of the ruling lowland Lao; and, the obstacles posed to a real unification of the country by continuing lack of security due to the war.

Nevertheless, Souvanna in 1967 renewed his attempts to promote national integration and cohesion through economic development, education, and administrative 
measures. An important role in this task was also played by government efforts to build up the Luang Prabang royal house as a symbol of national unity. In January, the Crown Prince visited the Nam Bac area -- a fertile valley some, 60 miles west of Dienbienphu and only recent1y recaptured from the Pathet Lao -- to show himself to the population. This was only the first of a number of royal tours which in 1967 gave many Lao their first chance to see their future king and to become conscious of "being a Lao." During the past year, Laos successfully overcame the disastrous damage of the 1966 flood and even managed to make some modest economic advances despite the civil war. This was due partly to the Lao government's own efforts to introduce budgetary controls and planning in a country where both had been virtually unheard of; to improve tax collection; to increase the efficiency of the customs service; and to reduce the graft and corruption for which Laos had become famous in the 1950's. Symbolic of this effort to enhance the role of the financial administration was the rise of an impressive building on Vientiane's Embassy Row. This was the new Ministry of Finance replacing the dingy quarters hitherto occupied by Sisouk's modest staff. 
But under conditions currently prevailing in wartorn Laos, local initiative can only make a very limited contribution to economic development. The country's per capita GNP is estimated at $\$ 60$ thus placing it at the bottom of the Asian income ladder, right below Nepal. Two thirds of the Lao budget currently goes to the support of the armed forces (numbering 70-80,000 men) whom the country's underdeveloped economy cannot possibly support out of its own resources. Since only one third of the national budget of Laos is now covered by ordinary revenues, international aid programs play a vital role in keeping Laos alive. Among these, the U.S. aid program is by far the most significant accounting for some $80 \%$ of all international assistance to Laos.

As in previous years, this U.S. aid program provided in 1967 the necessary funds for the struggle against the Pathet Lao and their Vietnamese allies, for resettlement and rehabilitation of the vast army of refugees from the war (averaging 250,000 at any one time) as well as for economic development. The overall size of the U.S. aid effort in Laos remained roughly at the level of the previous year -- about $\$ 55-60$ million plus an unspecified lamount going to military purposes. These aid efforts were 
for the most part directed toward three areas: agriculture, education, and road construction. Allocation of these American resources was guided in most cases as much by the objective of attaining political-social cohesion and reinforcing internal security as by considerations of economic development.

This was best illustrated by the so-called Sedone Valley program which reached its full capacity in 1967. The program spans portions of three provinces in Southern Laos. All U.S.-sponsored projects (schools, road construction, agricultural development, etc.) are coordinated with the Lao military efforts to remove Pathet Lao influence from the area inhabited by some 140,000 people. It was officially estimated that by the spring of the year almost two thirds of the population had been returned to government control.

Thanks to the influx of American aid, Laos in 1967 continued to make headway in the hitherto much neglected field of education. A new elementary school opened virtually every day somewhere in the country not excepting the tribal areas where the literacy rate is particularly low and illiteracy among adults is often close to $100 \%$. 1967 constituted something of a landmark in Lao education: 
an American-financed secondary school got underway in Vientiane. Here, for the first time in the country's history, most of the instruction will be offered in the Lao language rather than in the traditional French.

A U.S.-funded road-building program has obviously both implications for the development of a market economy and for the improvement of internal security. At the same time, it is hoped that it will eventually permit a drastic reduction of expenditures (running in excess of $\$ 10$ million per year) for air support of aid and relief operations in Laos. In 1967 substantial progress was made toward the completion of a north-south highway which, security permitting, will allow truck traffic all the way from Luang Prabang to the Cambodian border.

Economic progress during 1967 was particularly striking in the major towns along the Mekong, especially in Vientiane where traffic lights were being installed as Japanese-made motorcycles were beginning to pose a traffic problem. But even in the rural areas there were clear indications of the impact of the aid program: an increasing number of hamlets were benefiting from the completion of feeder roads and makeshift buses began to carry their human cargo and agricultural produce to the market centers. 
Little by little Laos is also entering the mainstream of Asian life through commodity exchanges and participation in regional organizations. In 1967, tourists coming up by plane from Bangkok were vying for space at the Lane Xang Hotel with members of the international Mekong Development Committee and a variety of international survey teams. The cornerstone was being laid for the first major power project in Laos, the internationally-financed $\$ 24$ million Nam Ngum Dam. Talks about a bridge and power lines linking Vientiane with Thailand across the Mekong River were entering the discussion stage. Another memorable event occurred in October of 1967: for the first time a resident of Vientiane could pick up the phone to call Luang Prabang or Savannakhet and even a number of cities in Thailand. Once isolated Laos is now rapidly emerging into the modern world.

No striking change in the military situation in Laos occurred during 1967. The Pathet Lao and their North Vietnamese sponsors continued to hold almost half of the country's territory, mostly a broad belt of mountainous terrain along the border of the two Vietnams. But they controlled no more than $20 \%$ of the total population of the country and these were for the most part tribal people. Even within underdeveloped Laos, the region held by the 
Pathet Lao is a particularly poor and undeveloped one. Hence the Pathet Lao were dependent on North Vietnamese assistance even more than their opponents were on help from the United States.

During the year, the Lao government maintained without much difficulty its power base in the more developed lowlands along the Mekong. Only occasionally did the Pathet Lao interfere with road traffic or ambush isolated posts. On the other hand, no place was absolutely safe from attack: even the Luang Prabang airfield was hit twice in the same year each time suffering the loss of some ten planes -- a substantial portion of the small Royal Lao air force.

On the whole, the FAR (Forces Armees Royales) did rather well in 1967 showing the effect of improved training and better coordination. They successfully cleaned out minor pockets of Pathet Lao resistance, withstood almost daily attacks by Pathet Lao and North Vietnamese units trying to recapture the valuable Nam Bac valley north of Luang Prabang. In the north, also, Meo General Vang Pao's guerrilla forces continued to harass the enemy. In the south, General Phasouk successfully compressed the Pathet Lao positions in the Lao Ngam area where they had been 
entrenched for the last 17 years. But neither side was strong enough or willing to take the risk of attacking the enemy's major positions: this applied especially to the Ho Chi Minh Trail area where North Vietnamese units rather than Pathet Lao forces had responsibility for defense. Even if no major battles were fought in Laos during 1967, the fighting there was bloodier than the absence of news about it in the international press would suggest. About $4 \%$ of the population (corresponding to 8 million men under U.S. conditions) were under arms and according to the Prime Minister's estimate casualties were running as high as 7,000 men per year -- a rate that would translate into half a million casualties on a U.S. population basis. Pathet Lao and North Vietnamese prisoners and defectors during 1967 confirmed the important role the North Vietnamese had come to play in maintaining a high level of insurgency in Laos. Not surprisingly, relations between the Vientiane government and Hanoi (which continued to recognize Souvanna's government rather than the Pathet Lao although it also maintained, as did China, a mission in NLHS territory at Khang

- Khay) went from bad to worse in 1967. This was in fact the major international development affecting Laos during that year. 
Early in 1967, Souvanna Phouma had'publicly attacked the North Vietnamese for interfering with armed forces in his country's affairs and he had drawn attention to the presence of 30,000 North Vietnamese combat troops on Laos soil. In September he announced that his Ambassador's mission in Hanoi had come to an end. Then, on October 13, speaking before the United Nations Souvanna drew the world's attention once more to the fact of North Vietnamese intervention. On that same day, in Vientiane, the Lao government put on display at a press conference a number of North Vietnamese prisoners and defectors who had rallied in Laos. Later on, while visiting Australia, he referred once more to the troubled situation in Laos and spoke of the areas under NLHS control as of a "new type of colony of North Vietnam."

While thus bringing maximum pressure to bear on Hanoi to withdraw its forces from Lao territory, Souvanna. remained faithful to his long-standing strategy of strengthening his position against outside intervention by maintaining the best possible relations with all other nations. Thus, during 1967, Souvanna not only cultivated the Soviet Union and the United States, he also sought to remain on cordial terms with the Chinese Communists and all his other 
neighbors. On the other hand, he did everything in his power to reduce the chances of war spilling over into Laos and turning the entire country -- rather than part of it -into a battlefield. Thus when asked in Canberra about his reaction to the idea of extending a barrier through Vietnam into Laos, he rejected this suggestion as detrimental to his country's interests for, in his view, such a line would tend tq encourage a widening of the war. "If we now have war in Laos," he stated, "it is at least a war which remains limited to certain regions."

In 1967, Souvanna's diplomacy had been unable to free his country from Hanoi's forces. As the war in Vietnam increased in scope and violence, it seemed doubtful whether - in 1968 he would even be able to preserve that modicum of peace Laos had been enjoying during the previous year. 


\section{Selected Reading}

Douze années d'intervention et d'agression des impérialistes américains au Laos, Editions du Neo Lao Haksat, 1966. $135 \mathrm{pp}$.

Fal1, Bernard, "The Pathet Lao: A 'Liberation Party'" in Robert A. Scalapino (ed.) The Communist Revolution in Asia, Prentice Hall, 1966, pp. 173-197. (A revised edition by Bernard Fall and Paul F. Langer is under preparation for publication in 1968.)

Kadymov, Gennadii G., Putj k nezavisimosti antilmperialisticheskaia bor'ba narodov V'etnama. Laosa, i Kambodji. 1945-1965, Moscow, 1966. 237 pp.

Larteguy, Jean, The Bronze Drums (Translated from the French, Les Tambours de bronze by Xan Fielding), Alfred A. Knopf, New York, 1967.420 pp.

Wagner, J. H., "The War in Laos: How to Make Diplomacy Cost Effective," Armed Forces Management, September 1967, pp. $43-46$. 